American Journal of Sports Science
2016; 4(1-1): 1 -8
Published online October 28, 2015 (http://www.sciencepublishinggroup.com/j/ajss)
doi: $10.11648 /$ j.ajss.s.2016040101.11
ISSN: $2330-8559$ (Print); ISSN: $2330-8540$ (Online)

\title{
Somatotype Characteristics of School Boys Aged Six to Eleven Years from Nepal
}

\author{
Anup Adhikari ${ }^{1, ~ *}$, N. P. Sinha ${ }^{2}$ \\ ${ }^{1}$ Anthropometrica, Toronto, Ontario, Canada \\ ${ }^{2}$ Kathmandu University School of Medical Sciences, Kathmandu University, Dhulikhel, Nepal \\ Email address: \\ dranupadhikari@yahoo.com (A. Adhikari)
}

To cite this article:

Anup Adhikari, N. P. Sinha. Somatotype Characteristics of School Boys Aged Six to Eleven Years from Nepal. American Journal of Sports Science. Special Issue: Academic Research for Multidisciplinary. Vol. 4, No. 1-1, 2016, pp. 1-8. doi: 10.11648/j.ajss.s.2016040101.11

\begin{abstract}
Nine hundred and ninety seven school children of Nepal age ranged from 6 to 11 year were studied for their somatotype characteristics. Endomorphy-Mesomorphy-Ectomorphy components were calculated using Heath-Carter Somatotype method. Average Endomorphy components for 6,7,8,9,10, and 11 year old boys were 3.0 ( \pm 1.8$)$, 3.3( \pm 1.8$)$, $3.1( \pm 1.4), 2.7( \pm 1.0), 3.0( \pm 1.2)$ and $2.7( \pm 0.7)$ respectively. Average mesomorphy components for $6,7,8,9,10$,and 11 year old boys were $4.2( \pm 0.6), 4.2( \pm 1.0), 4.0( \pm 1.1), 3.8( \pm 0.9), 4.0( \pm 0.8)$ and 3.7( \pm 0.9$)$ respectively. Average ectomorphy components for $6,7,8,9,10$ and 11 year old boys were $2.3( \pm 1.1), 2.3( \pm 1.0), 2.5( \pm 1.3), 2.8( \pm 1.1), 2.9( \pm 1.0)$ and $3.2( \pm 1.3)$ respectively. Slightly higher adiposity was observed for the Nepali male children compared to their similar counterparts of other different countries. But muscularity and linearity characteristics of the Nepali boys were very similar to other countries. The body type gradually changed into balanced mesomorph at the age of 9 and $10 \mathrm{yr}$ which again changed into ectomorphic mesomorph but very close to central at the age of $11 \mathrm{yr}$. The changes of body type from endomorphic mesomorph into balanced mesomorph and ultimately into ectomorphic mesomorph supported the trend of somatotype change with age.
\end{abstract}

Keywords: Somatotype, Endomorphy, Mesomorphy, Ectomorphy, Nepal, Children

\section{Introduction}

The somatotype is the morphological characteristic of the body built which is a phenotypic entity capable of changes with ageing, growth, exercise and nutrition [1]. It is defined as the quantification of the present shape and composition of the human body and expressed in a three -number rating components representing endomorphy, mesomorphy and ectomorphy respectively, always in same order. Endomorphy is the relative fatness, mesomorphy is the relative musculo skeletal magnitude, and ectomorphy is the relative linearity or thinness of the physique [2]. It is important to recognize the somatotype as a description of the body in general, and does not answer more specific questions related to the specific dimensions of the body [1].

Heath-Carter phenotypic somatotype ratings, covering as they do wide variations in shape, absolute and relative body size, and body composition, are well suited for analyzing the widely recognized changes in human beings during growth, maturation and process of aging [1].With minor limitations, the Heath and Carter method (1967) can be applied to both sexes at all ages for studying growth and maturation[3]. By itself, anthropometric somatotype is an estimation of criterion rating, but it may be less valid for young children than for older children and adults. But several investigators have used anthropometric somatotypes for studying growth pattern of children from 1 to $11 \mathrm{yr}$ old using Heath-Carter Somatotype technique[4].

Nepal is a landlocked country in South Asia and one of the poorest nations in the world. The country is a developing country with a low income economy and average per capita daily supply of food energy is $89 \%$ of the requirement [5]. Most of the previous data available on Nepali children were based on clinical and nutritional aspects figuring nutritional status related to growth and development.No study had been done till date on somatotype characteristics of Nepali children. Most of the studies were either on physical characteristics or on nutritional aspects $[6,7,8,9,10,11]$. It was well known that population differences in mean somatoypes could be attributed to nutritional or activity adaptations as well as to genetic background $[12,13]$. The present study was designed to collect a cross-sectional data on somatotype characteristics of Nepali male children living in hilly areas 
next to mountain zone of Nepal. Hence, the present study was aimed to evaluate the growth and development of somatotype characteristic of Nepali male children aged between 6 and 11 yr living in hilly zone of Nepal.

\section{Method}

The study followed the ethical part of ethics in studies in humans of Kathmandu University School of Medical Sciences, Dhulikhel, Nepal. Subject's consent was obtained according to the norms for human experimentation. Permission for each student was taken from their parents through school authorities prior to the measurement. The study was carried out during the year 2009.

\subsection{Study Design}

It was a cross sectional study for Nepali male school children in the year of 2009. The study was designed as a part of educational project for the students of Human Physiology, department of Physiology, Kathmandu University School of Medical Sciences, Dhulikhel, Nepal.

\subsection{Subjects}

997 male students of local primary schools were randomly selected for evaluating their somatotype characteristics. The primary level school education in Nepal comprises of grades I-V.Thus the age range of the present study was in between 6 and 11 yr. Children were from primary schools of Kavrepalanchok district of Nepal. Most of the students were from middle and lower middle socio-economic class and from different ethnic groups of Nepal like Newars, Brahmins, Chettris and Tamangs.

\subsection{Age Group}

Age groups were formed by rounding up either five months or more into a complete next year or less than five months into previous year. Thus, followings were the six age groups with age limit of $6 \mathrm{yr}$ (65 - 76 month ), $7 \mathrm{yr}(77-88$ moth), 8 yr (89-100 month), 9 yr (101-112 month), 10 yr( 113-124 month) and 11 yr ( 125-136 month).

\subsection{Statistical Analysis}

Data were analyzed with Statistical Package SPSS (IBM) version 20. Mean, standard deviation and correlation coefficient were analyzed.

\subsection{Phantom ' $z$ " Score}

The relative magnitudes of physical characteristics with respect to stature were assessed with "Phantom z scores" $[14,15,16]$

\subsection{Anthropometric Measurements}

Anthropometric measurements were done on same day for each boy in same session to avoid technical error. Measurements were done by a level 4 criterion
Anthropometrist accredited by International Society for the Advancement of Kinanthropometry,ISAK [17]. Methods described in the ISAK manual [18] were followed. Stature was measured with an Anthropometric Rod and body mass was measured with an electronic weighing scale. Skinfold thicknesses were measured with a Harpenden skinfold caliper (Baty International, UK). Anthropometric tape (Lufkin) and sliding caliper (Rosscraft, Canada) were used to measure circumferences and bone diameters respectively.

\subsection{Somatotype}

Heath - Carter [19] method was followed for somatotype rating. The following equations were used for calculating somatotype.

$$
\begin{gathered}
\text { Endomorphy }=-0.7182+0.1451 \times \sum \mathrm{SF}-0.00068 \times \sum \mathrm{SF} 2 \\
+0.0000014 \times \sum \mathrm{SF} 3
\end{gathered}
$$

where $\sum \mathrm{SF}=$ (sum of triceps, subscapular and supraspinale skinfolds) multiplied by (170.18/height in $\mathrm{cm})$. This was called height-corrected endomorphy and was preferred method for calculating endomorphy)

Mesomorphy $=0.858 \times$ humerus breadth $+0.601 \times$ femur breadth $+0.188 \times$ corrected arm girth $+0.161 \times$ corrected calf girth - height $\times 0.131+4.5$

Three different equations were used to calculate ectomorphy according to the height -weight ratio (HWR):

If HWR was greater than or equal to 40.75 then, Ectomorphy $=0.732 \times$ HWR -28.58

If HWR was less than 40.75 and greater than 38.25 then, Ectomorphy $=0.463 \times \mathrm{HWR}-17.63$

If HWR was equal to or less than 38.25 then, Ectomorphy $=0.1$

\section{Result}

Table 1 showed the physical and anthropometrical characteristics of 997 male Nepali children age ranged from 6 to $11 \mathrm{yr}$. Height increased gradually as age increased. Table 1 also showed the skinfold thicknesses of biceps, triceps, subscapular, supraspinale and medial calf along with arm girth, calf girth, biepicondylar humerus and femur diameters. Average Body Mass Index (BMI) of all ages were between 16.2 and $17.0 \mathrm{~kg} . \mathrm{m}^{-2}$ indicating underweight category (Table 1). Body Mass Index did not change with age. Three different components in average were shown in Table 1. Average endomorphic components for all age groups were less than 3.3 but more than 2.7 whereas maximum average mesomorphic components were 4.2 observed for the age group of 6 and $7 \mathrm{yr}$. The 8 and $10 \mathrm{yr}$ old boys were also possessed an average value of 4.0. Less values were observed for age group of 9 and $11 \mathrm{yr}$ which were 3.8 and 3.7 respectively ( Table 1). Table 2 showed the correlation coefficient among the different variables when correlated with each other.

Height, weight, humerus and femur diameters showed a significant correlation when correlated with age. Table 3 showed a comparative somatotype of male children of 
different countries reported by different authors including the present study.

Table 1. Physical characteristics, skinfold thicknesses and somatotype components of Nepali boys aged 6 to 11 years.

\begin{tabular}{|c|c|c|c|c|c|c|c|}
\hline Age (yr) & Total & $6 \mathrm{yr}$ & $7 \mathrm{yr}$ & $8 \mathrm{yr}$ & $9 \mathrm{yr}$ & $10 \mathrm{yr}$ & $11 \mathrm{yr}$ \\
\hline \multirow[t]{2}{*}{ Number (n) } & 997 & 103 & 153 & 108 & 225 & 207 & 201 \\
\hline & Mean & 116.9 & 119.2 & 126.0 & 128.1 & 133.7 & 137 \\
\hline \multirow[t]{3}{*}{ Height (cm) } & SD & 5.0 & 5.4 & 4.3 & 6.0 & 5.7 & 4.8 \\
\hline & Range & $105.7-124.5$ & $107.2-127.1$ & $118.6-131.6$ & $113.2-140.7$ & $123.7-145.6$ & $131.8-146$ \\
\hline & Mean & 22.3 & 23.5 & 27.0 & 27.3 & 30.3 & 31.9 \\
\hline \multirow[t]{2}{*}{ Weight (kg) } & SD & 5.8 & 4.5 & 5.3 & 5.1 & 5.0 & 4.0 \\
\hline & Range & $15.5-37.5$ & $19-34$ & $21.5-39.5$ & $17.0-38.0$ & $23.5-49.0$ & $25.0-37.5$ \\
\hline \multirow{3}{*}{$\begin{array}{l}\text { Biceps } \\
\text { skinfold(mm) }\end{array}$} & Mean & 6.2 & 5.9 & 6.4 & 5.5 & 5.9 & 6.0 \\
\hline & SD & 2.8 & 2.4 & 2.3 & 2.0 & 2.4 & 1.6 \\
\hline & Range & $4.0-13.6$ & $3.2-13$ & $3.0-11.0$ & $2.6-13.0$ & $3.2-13.8$ & $3.2-8.8$ \\
\hline \multirow{4}{*}{$\begin{array}{l}\text { Triceps } \\
\text { skinfold(mm) }\end{array}$} & Mean & 9.5 & 9.9 & 10.0 & 8.7 & 10.7 & 9.6 \\
\hline & SD & 5.4 & 4.1 & 4.4 & 2.6 & 4.5 & 2.5 \\
\hline & Range & $4-24.2$ & $5-21$ & $4.8-18.6$ & $4.6-16.6$ & $5.4-20.2$ & $4.8-12.6$ \\
\hline & Mean & 7.3 & 8.0 & 6.9 & 6.3 & 7.0 & 6.4 \\
\hline \multirow[t]{3}{*}{ Subscapulare skinfold (mm) } & SD & 6.4 & 6.6 & 3.3 & 2.5 & 2.4 & 1.1 \\
\hline & Range & $3.2-26$ & $4.4-27.4$ & $4.6-16.4$ & $3.4-16.6$ & $4.4-34.2$ & $4-8.4$ \\
\hline & Mean & 5.4 & 6.2 & 6.1 & 5.4 & 6.3 & 5.7 \\
\hline \multirow[t]{2}{*}{ Supraspinale skinfold (mm) } & SD & 4.8 & 5.2 & 3.5 & 3.0 & 1.2 & 1.7 \\
\hline & Range & $2.4-19.4$ & $3.2-23.6$ & $3-13.1$ & $2.6-16$ & $2.8-30$ & $3-8$ \\
\hline \multirow{3}{*}{$\begin{array}{l}\text { Calf skinfold } \\
(\mathrm{mm})\end{array}$} & Mean & 10.1 & 8.7 & 11.3 & 9.1 & 9.3 & 10.1 \\
\hline & SD & 5.0 & 3.4 & 6.2 & 3.8 & 4.0 & 3.6 \\
\hline & Range & $3.2-22.2$ & $5.4-16.6$ & $4-27.6$ & $4-18.7$ & $5-22.5$ & $5.4-16.4$ \\
\hline \multirow{3}{*}{$\begin{array}{l}\text { Humerus breadth } \\
(\mathrm{cm})\end{array}$} & Mean & 4.8 & 4.9 & 5.0 & 5.1 & 5.4 & 5.5 \\
\hline & SD & 0.3 & 0.4 & 0.4 & 0.5 & 0.3 & 0.4 \\
\hline & Range & $4.2-5.4$ & $4.3-5.5$ & $4.2-5.7$ & $4.3-6.0$ & $5-6.3$ & $5.2-5.9$ \\
\hline \multirow{3}{*}{$\begin{array}{l}\text { Femur breadth } \\
(\mathrm{cm})\end{array}$} & Mean & 7.2 & 7.2 & 7.5 & 7.5 & 8.0 & 8.1 \\
\hline & SD & 0.4 & 0.3 & 0.4 & 0.6 & 0.3 & 1.6 \\
\hline & Range & $6.6-7.9$ & $6.7-7.9$ & $7-8.2$ & $6.5-8.8$ & $7.6-9.1$ & $7.4-8.6$ \\
\hline \multirow{3}{*}{$\begin{array}{l}\text { Arm girth relaxed } \\
(\mathrm{cm})\end{array}$} & Mean & 17.0 & 17.2 & 19.3 & 17.9 & 18.9 & 19.1 \\
\hline & SD & 2.6 & 3.0 & 3.9 & 1.6 & 2.1 & 1.6 \\
\hline & Range & $14.6-23.5$ & $9.2-23$ & $16.4-30$ & $14.8-21$ & $16.5-24$ & $16.5-22$ \\
\hline \multirow{3}{*}{$\begin{array}{l}\text { Calf girth } \\
(\mathrm{cm})\end{array}$} & Mean & 22.9 & 24.4 & 25.0 & 25.7 & 26.8 & 27.1 \\
\hline & SD & 1.7 & 2.0 & 2.7 & 2.2 & 2.0 & 2.3 \\
\hline & Range & $21-25.6$ & $22.3-29.5$ & $22-33$ & $22.4-29.8$ & $22.7-32$ & $22.4-30.5$ \\
\hline \multirow{3}{*}{ Endomorph } & Mean & 3.0 & 3.3 & 3.1 & 2.7 & 3.0 & 2.7 \\
\hline & SD & 1.8 & 1.8 & 1.4 & 1.0 & 1.2 & 0.7 \\
\hline & Range & $1.3-8.1$ & $1.9-8.6$ & $1.5-6.1$ & $1.2-6.4$ & $1.4-8.3$ & $1.3-3.6$ \\
\hline \multirow{3}{*}{ Mesomorph } & Mean & 4.2 & 4.2 & 4.0 & 3.8 & 4.0 & 3.7 \\
\hline & SD & 0.6 & 1.0 & 1.1 & 0.9 & 0.8 & 0.9 \\
\hline & Range & $3.1-5.1$ & $3.0-7.1$ & $2.4-6.2$ & $2.1-6.1$ & $3.0-5.6$ & $2.4-5.1$ \\
\hline \multirow{3}{*}{ Ectomorph } & Mean & 2.3 & 2.3 & 2.5 & 2.8 & 2.9 & 3.2 \\
\hline & SD & 1.1 & 1.0 & 1.3 & 1.1 & 1.0 & 1.3 \\
\hline & Range & $0.1-3.5$ & $0.1-4.1$ & $0.1-4.5$ & $0.1-4.7$ & $0.4-4.9$ & $1.3-5.1$ \\
\hline \multirow{3}{*}{$\operatorname{BMI}\left(\mathrm{kg} \cdot \mathrm{m}^{-2}\right)$} & Mean & 16.2 & 16.4 & 16.9 & 16.6 & 16.8 & 17.0 \\
\hline & SD & 3.0 & 2.6 & 2.7 & 2.5 & 1.8 & 1.9 \\
\hline & Range & $13.6-24.2$ & $13.8-24.3$ & $13.7-23.5$ & $13.3-25.0$ & $14.3-24.2$ & $14.0-20.0$ \\
\hline
\end{tabular}

Table 2. Correlation coefficients among the anthropometric variables $(*$ significant at $p<.001)$.

\begin{tabular}{llllllllll}
\hline & Age & Height & Weight & Humerus & Femur & Endo & Meso & Ecto & BMI \\
\hline Age & 1 & $0.78^{*}$ & $0.54^{*}$ & $0.53^{*}$ & $0.58^{*}$ & -0.09 & -0.16 & 0.29 & 0.09 \\
Height & & 1 & $0.76^{*}$ & $0.75^{*}$ & $0.77^{*}$ & 0.05 & -0.17 & 0.26 & 0.24 \\
Weight & & & 1 & $0.84^{*}$ & $0.85^{*}$ & $0.60^{*}$ & 0.40 & -0.34 & $0.80^{*}$ \\
Humerus & & & & 1 & $0.83^{* *}$ & 0.38 & 0.38 & -0.19 & $0.56^{*}$ \\
Femur & & & & & 1 & 0.35 & $0.70^{*}$ & -0.21 & $0.57^{*}$ \\
Endomorphy & & & & & & 1 & $0.69^{*}$ & $-0.74^{*}$ & $0.87^{*}$ \\
Mesomorphy & & & & & & & 1 & $-0.85^{*}$ & $0.75^{*}$ \\
Ectomorphy & & & & & & & & & 1 \\
BMI & & & & & & & & & $-0.82^{*}$ \\
\hline
\end{tabular}

Fig 1 showed the mean somatotype components of the Nepali children at different ages. Fig 2 represented the body magnitude of physical characteristics with respect to stature of the Nepali children at different ages. Fig 3-9 showed the somatotype of the male boys at specific ages from different countries. 


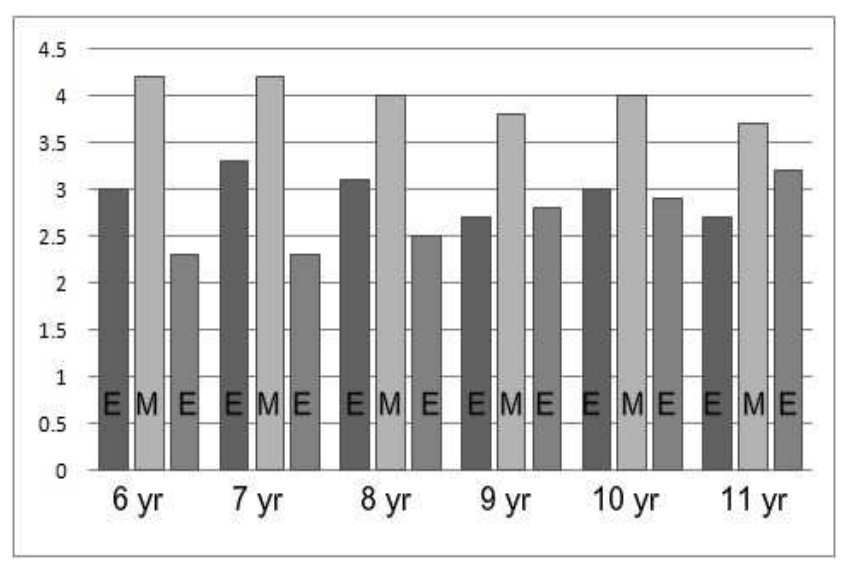

Fig. 1. Somatotype components of Nepali children E=Endomorphy, $M=$ Mesomorphy, E=Ectomorphy).

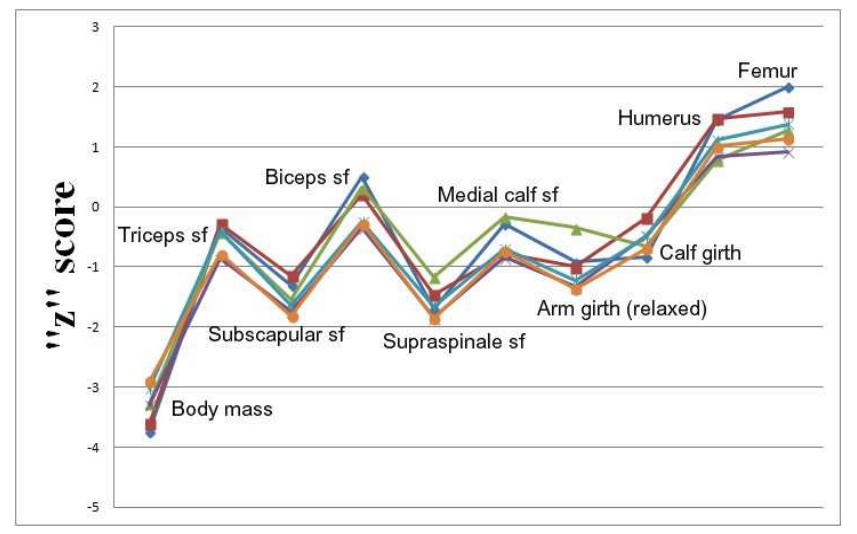

Fig. 2. Relative body magnitude of physical characteristics with respect to stature of the Nepali children at different ages.

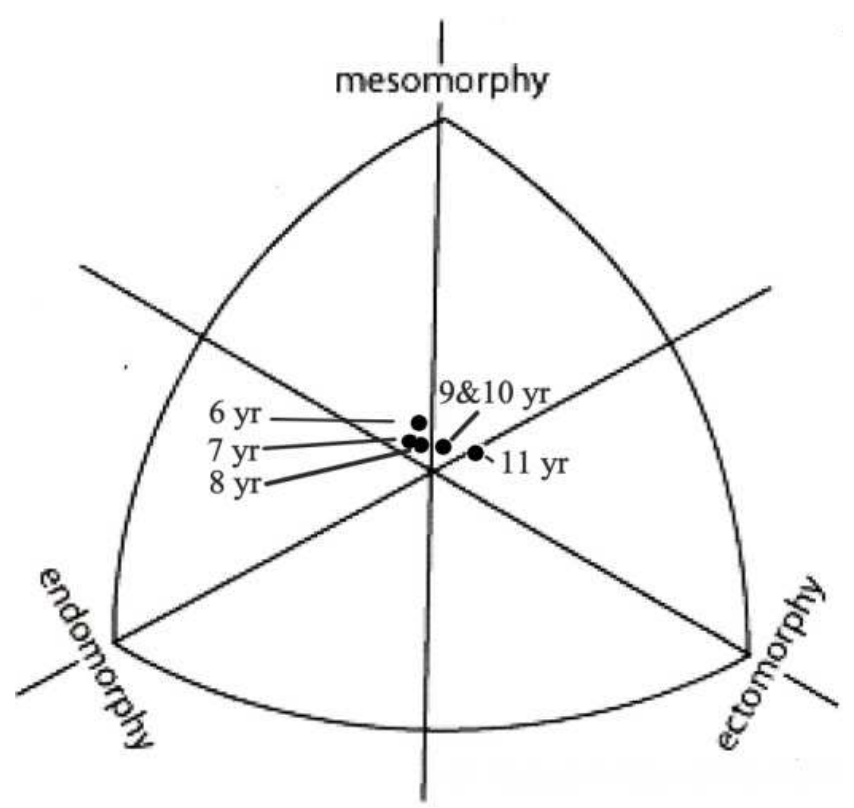

Fig. 3. Somatotype of Nepali boys at different age group(present study).

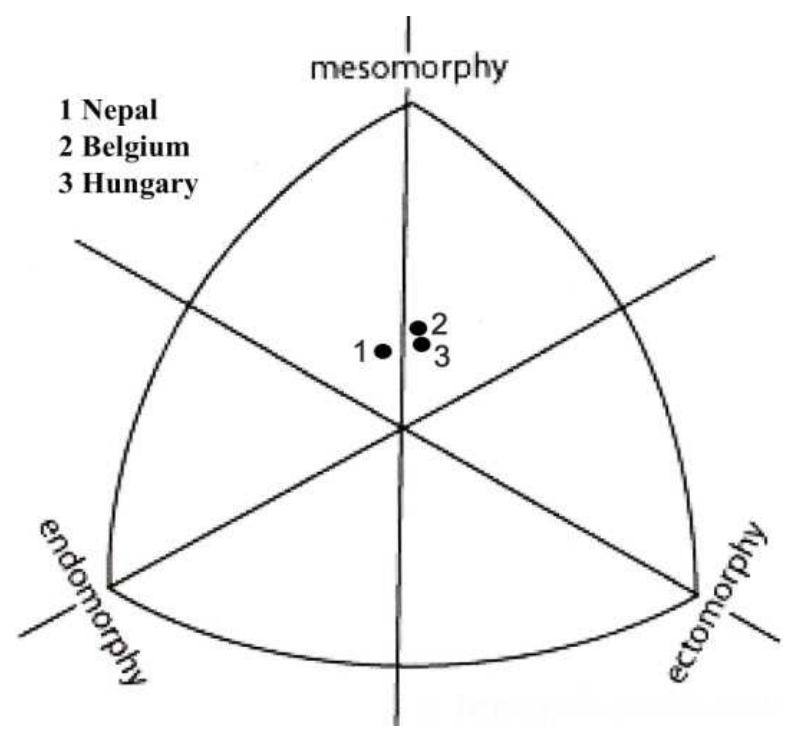

Fig. 4. Somatotype of 6 year old boys of different countries.

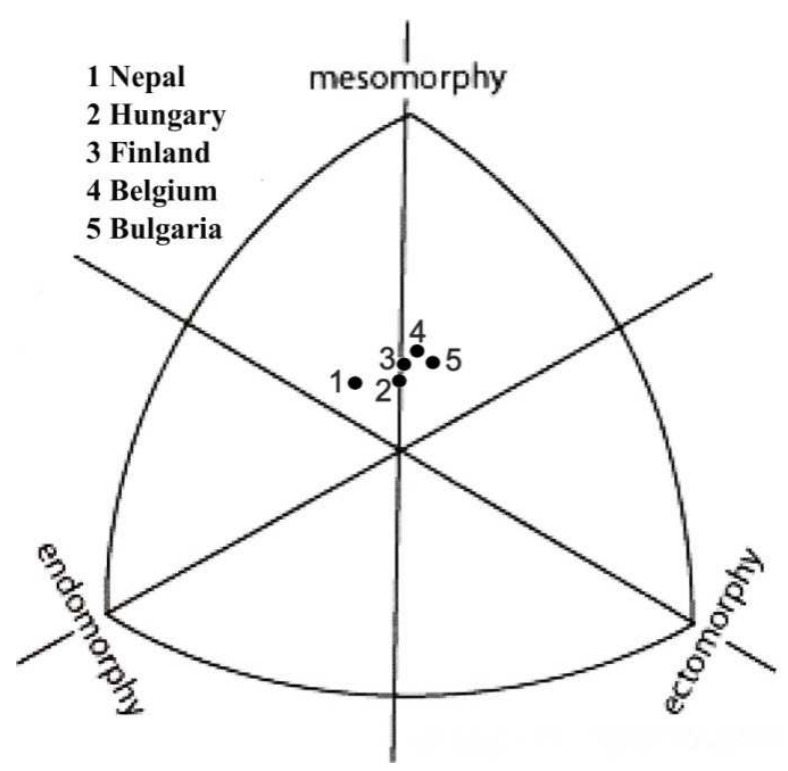

Fig. 5. Somatotype of 7 year old boys of different countries.

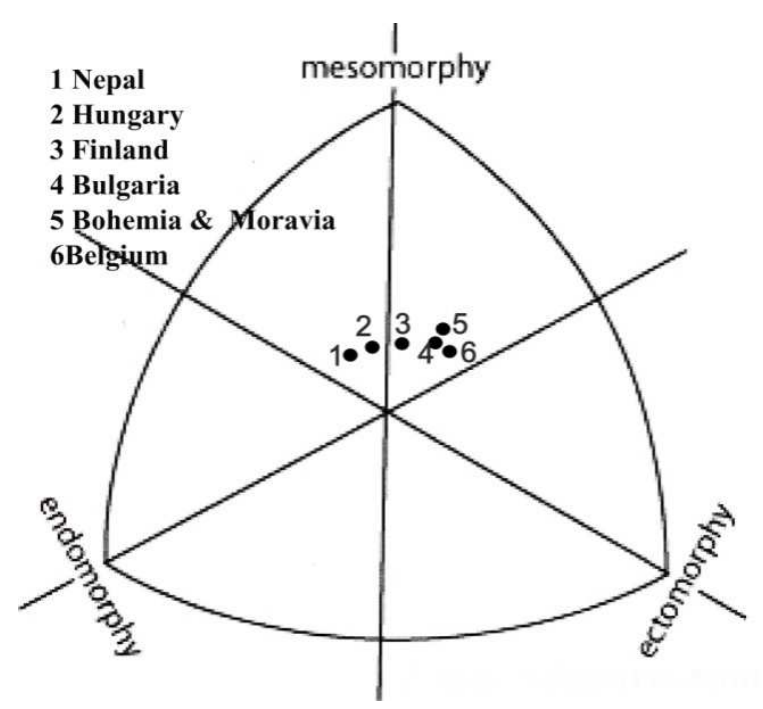

Fig. 6. Somatotype of 8 year old boys of different countries. 
Table 3. Mean somatotype of male children by age in cross-sectional studies using Heath-Carter method.

\begin{tabular}{|c|c|c|c|c|}
\hline Study & Country & Age (yr) & Number & Somatotype \\
\hline \multirow{6}{*}{ Duquet, 1980} & \multirow{6}{*}{ Belgium } & 6 & 149 & $2.0-4.2-2.4$ \\
\hline & & 7 & 409 & $2.0-4.0-2.4$ \\
\hline & & 8 & 469 & $1.9-3.8-3.1$ \\
\hline & & 9 & 536 & $2.0-3.7-3.3$ \\
\hline & & 10 & 536 & $2.1-3.6-3.5$ \\
\hline & & 11 & 871 & $2.1-3.5-3.7$ \\
\hline \multirow{3}{*}{ Štêpnicka, 1976} & Bohemia & 8 & 101 & $2.3-4.5-3.2$ \\
\hline & Moravia & 10 & 101 & $2.3-4.2-3.8$ \\
\hline & & 9 & 20 & $2.7-4.6-3.0$ \\
\hline \multirow[t]{2}{*}{ Farmosi, 1982} & Hungary & 10 & 28 & $2.3-4.4-3.4$ \\
\hline & & 11 & 39 & $2.6-4.3-3.8$ \\
\hline \multirow[t]{3}{*}{ Guedes, 1983} & Brazil & 11.5 & 30 & $2.6-4.0-3.5$ \\
\hline & & 6 & 41 & $2.5-4.1-2.3$ \\
\hline & & 7 & 78 & $2.8-4.1-2.8$ \\
\hline \multirow{4}{*}{ Eiben, 1985} & Hungary & 8 & 80 & $3.3-4.0-3.0$ \\
\hline & חungaly & 9 & 94 & $3.4-3.9-3.4$ \\
\hline & & 10 & 59 & $3.7-3.8-3.5$ \\
\hline & & 11 & 94 & $3.7-3.8-3.7$ \\
\hline \multirow[t]{3}{*}{ Slaughter et al, 1977b } & USA & $7-12$ & 68 & $2.6-4.1-3.3$ \\
\hline & & 7 & 18 & $2.6-4.3-2.7$ \\
\hline & & 8 & 46 & $2.5-4.2-2.9$ \\
\hline \multirow{4}{*}{ Holopainen et al,1984 } & Finland & 9 & 44 & $2.7-3.9-3.3$ \\
\hline & Fimiand & 10 & 48 & $3.2-4.0-3.1$ \\
\hline & & 11 & 42 & $3.4-4.2-3.0$ \\
\hline & & 12 & 12 & $2.5-3.1-4.6$ \\
\hline \multirow{4}{*}{ Toriola and Igbokwe, 1985} & & 10 & 25 & $2.5-3.7-2.9$ \\
\hline & Nigeria & 11 & 32 & $2.8-3.7-2.7$ \\
\hline & & 7 & 48 & $2.05-4.25-2.88$ \\
\hline & & 8 & 56 & $2.3-4.3-3.24$ \\
\hline \multirow[t]{3}{*}{ Mladenova et al, 2010} & Bulgaria & 9 & 56 & $2.48-4.09-3.56$ \\
\hline & & 10 & 55 & 2.26-4.06-3.97 \\
\hline & & 11 & 39 & $2.71-4.32-3.65$ \\
\hline Meeli Saar, 2008 & Estonia & $10-11$ & 56 & $2.0-4.0-3.7$ \\
\hline Marta et al, 2011 & Portugal & $10.8( \pm 0.4)$ & 152 & $3.62-4.69-2.49$ \\
\hline Tapia et al, 2013 & Chile & 11 & 174 & $5.0-4.8-1.8$ \\
\hline Goon et al, 2013 & Nigeria & $7-10$ & 21 & $1.02-2.2-2.29$ \\
\hline \multirow{6}{*}{ Present study } & \multirow{6}{*}{ Nepal } & 6 & 103 & $3.0-4.2-2.3$ \\
\hline & & 7 & 153 & $3.3-4.2-2.3$ \\
\hline & & 8 & 108 & $3.1-4.0-2.5$ \\
\hline & & 9 & 225 & $2.7-3.8-2.8$ \\
\hline & & 10 & 207 & $3.0-4.0-2.9$ \\
\hline & & 11 & 201 & $2.7-3.7-3.2$ \\
\hline
\end{tabular}

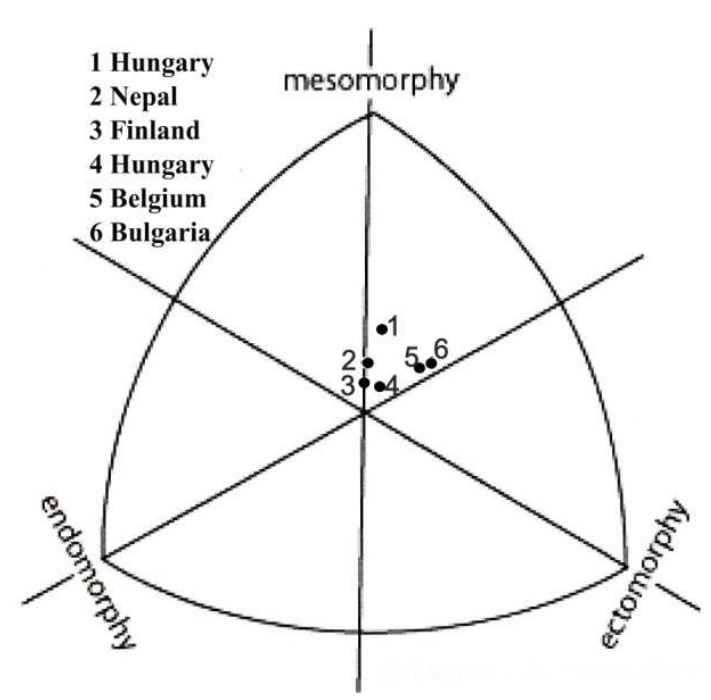

Fig. 7. Somatotype of 9 year old boys of different countries.

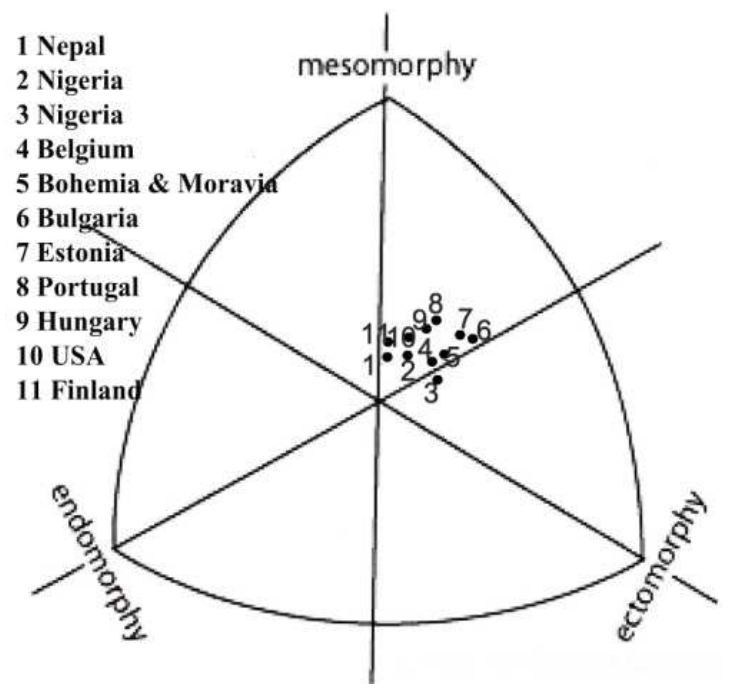

Fig. 8. Somatotype of 10 year old boys of different countries. 


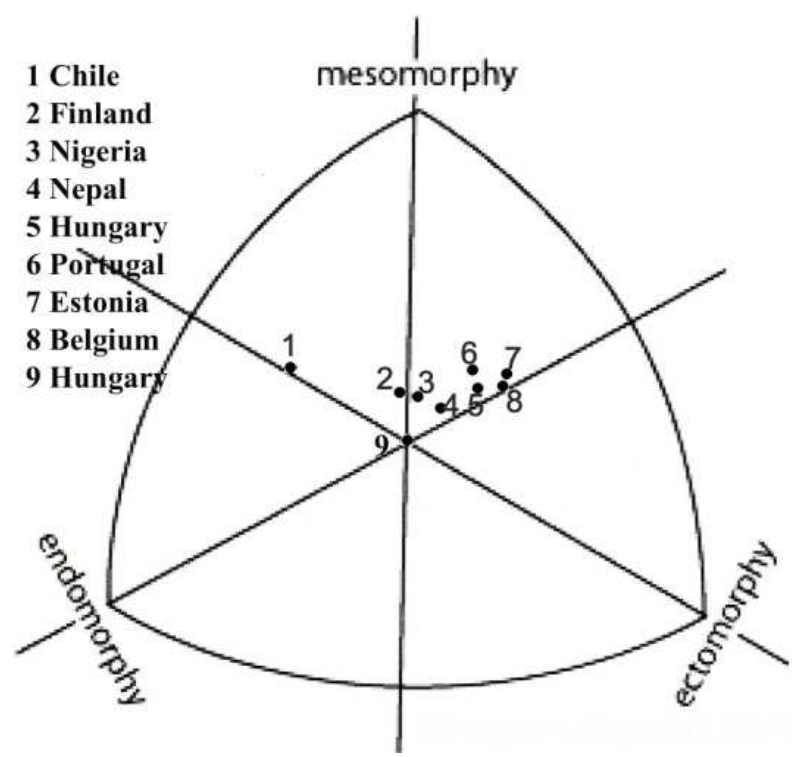

Fig. 9. Somatotype of 11 year old boys of different countries.

\section{Discussion}

The somatotype, the phenotype character, changes with growth, ageing, physical exercise and nutrition [1]. Different studies revealed that somatotype exhibits significant changes in adolescence [20,21]. When puberty begin in man, their somatotype increases in mesomorphy and ectomorphy but decreases in endomorphy, due to reduction of subcutaneous fat of the upper and lower limbs and lower and dorsal regions of the thorax. Different factors like nutrition and physical activity are critical in modifying each somatotype component during the adolescent period [20,22].

Endomorphic component represented the adiposity of a body. The average endomorphic components of 6,7,8,9 and $10 \mathrm{yr}$ old Nepali boys of the present study were higher than their similar counterparts of Belgium [23], Bohemia \& Moravia[24], Hungary[25], Brazil[26], Nigeria [27], Bulgaria [28] and Estonia [29].The endomorphy component of the children of the above mentioned age groups of different countries were between 1.02 and 2.8 whereas that of the Nepali children was $3.0( \pm 1.8)$ with a range between 1.3 and 8.1 ( Table 3).Nepali boys of the present study possessed low values than the Finish boys [30] aged 10 and $11 \mathrm{yr}$ ( Table 1). Similarly, the Portuguese[31] and Chilean[21] boys of 10 and $11 \mathrm{yr}$ old possessed more endomorphy component than the Nepali boys of same age groups (Table 3). Thus, slightly higher adiposity was the trait of Nepali male children compared to European and Latin American children except for the Portugal and Chile.

Mesomorph component represented muscularity. Mesomorphy components of the present study were between 4.0 and 4.2 in average for all age groups except for 9 and 11 yr where the values were 3.7 and 3.8 respectively (Table 1).Nepali boys possessed very similar values with the boys of same age groups of Belgium [23], Bohemia \&Moravia [24], Hungary[25,33], Brazil[26], USA[31], Finland[29], Nigeria[27], Bulgaria[22], Estonia[28], except for few cases.
Hungarian boys with age ranged from 8 to 10 , studied by Eiben [32], possessed low muscularity in terms of mesomorphy component (Table 3). While Štêpnicka [24] observed a higher value of 4.6 for mesomorphy component for the 8 years old Bohemia \& Moravia boys, Marta et al [30] also observed a slightly higher value of 4.69 for the Estonian $10.8( \pm 0.4)$ yr old boys. Similarly, Tapia et al [21] reported a higher average value of 4.8 for mesomorphy component for the 11 yr old Chileans boys. Hence, the muscularity trait of the Nepali boys of the present study was very similar to the other nations' boys of same age groups except the $11 \mathrm{yr}$ old Latin American boys.

The third somatotype component, the ectomorphy expressed the relative linearity of the body. In the present study, the average ectomorphy components of the boys age ranged from 6 to $11 \mathrm{yr}$ were between 2.3 and 3.2. The values were very similar or slightly lower than the reported values of other studies for different countries [22-32]. Thus, linearity trait of the Nepali boys of the present study was very similar to the boys of other western countries with similar age.

In general, boys at young age move from endomesomorphy to ecto-mesomorphy and balanced ectomorphymesomorphy as they grew up. During adolescence, with increased muscle mass and complete ossification, mesomorphy component increases and ectomorph component decreases [33]. The general tendency to an increase in endomorphy, a decrease in mesomorphy and an increase in ectomorphy during growth is apparent in children $[29,33]$. In the present study, endomorphic mesomorph physique of 6,7 and 8 yr old Nepali boys changed into balanced mesomorph physique between 9 and 10th yr which finally changed into ectomorphic mesomorph (very close to central) at 11th yr ( Table 1and Fig 2 \&3). The changes in physique from endomorphic mesomorph to balanced mesomorph and finally into ectomorphic mesomorph supported the trend of somatotype changes with age [22,3235]. Heath and Carter [33] indicated chances of increased mesomorph and decrease ectomorph components during adolescence but they also mentioned the chances of relatively stable somatotype in some children during adolescent period [33]. In the present study, the gradual changes in physique as age increased might be due to increased physical activities where children had to perform more physical work to maintain their daily life activities including climb up and down on hills. Ethnical issues could not be ignored as ethnical differences of physique were also reported by different authors [4]. More studies were required to make a final conclusion.

When correlated with age, the three somatotype components did not show any significant relationships (Table 2). But ectomorphy character increased as age increased, supporting the change of body type towards more linear. Body mass showed a significant relationship with biepicondylar humerus width $(\mathrm{r}=0.84, \mathrm{p}<.05)$ and biepicondylar femur width $(\mathrm{r}=0.85, \mathrm{p}<05)$. This might be due to increased mesomorphy component during the period of 
growth and development. Positive associations were observed between age and humerus width $(\mathrm{r}=0.53, \mathrm{p}<.05)$ as well as between age and femur width $(r=0.58, \mathrm{p}<0.5)$. A high relationship was observed between femur and mesomorphy component $(\mathrm{r}=0.70, \mathrm{p}<.05)$. Thus, though three somatotype components did not increase as age increased, but mesomorph components increased gradually with corresponding femur width. More studies were needed for final statement.

\section{Conclusion}

From the above discussion it might be concluded that the somatotype trait of the Nepali male school children who lived in hilly region was not different from the traits obtained for European, American and Latin American children. The present study also supported the theory of changes in the somatotypological characteristic with age.

\section{Acknowledgement}

Authors were highly indebted to Dr. Rajendra Koju, Cardiologist, Dhulikhel Hospital, Dhulikhel, Nepal for his cooperation during the study. Authors were also grateful to the school committees along with the teachers who cooperated during the study.

\section{References}

[1] Carter,J.E.L. and Heath,B.H., Somatotyping -Developments and applications, Cambridge University Press, Cambridge, 1990,pp. 182-197.

[2] Norton, K.,and Olds, T., Anthropometrica- A textbook of body measurement for sports and health courses,University of New South Wales Press Ltd, Sydney, Australia, 1986,pp.148-156.

[3] Heath,B.H., and Carter, J.E.L., A modified somatotype method, American journal of Physical Anthropology, 1967, 27: 57-74.

[4] Carter, J.E.L. and Heath,B.H., Somatotyping -Developments and applications, Cambridge University Press, Cambridge, 1990,pp 141-181.

[5] Moock, P.R., and Leslie, J., Childhood malnutrition and Schooling in the Terai Region of Nepal, World Bank Reprint Series: Number 379, Journal of Development Economics, 1986, 20: $33-52$.

[6] Farquharson, S.M., Growth patterns and nutrition in Nepali children, Archives of Disease in Childhood, 1976, 51:3-15.

[7] Devakumar, D.,Grijalva-Eternod, C.S., Roberts, S., Chaube,S.S., Saville, N.M., Manandhar, D.S., Costello, A., Osrin, D., and Wells, J.C.K. Body composition in Nepalese children using isotope dilution: the production of ethnic-specific calibration equations and an exploration of methodological issues, PeerJ, 2015,3:785-797.

[8] Khatri,R.B.,Mishra, S.R.,Khanal, V.,and Choulagai,B., Factors associated with underweight among children of FormarKamaiyas in Nepal,Frontiers in Public Health, 2015.
[9] Nepal, A.K., Gelal,B., Mehta, K., Lamsal, M., Pokharel, P.K., and Baral,N., Plasma zinc levels, anthropometric and sociodemographic characteristics of school children in eastern Nepal, BMC Research Notes, 2014, 7:18-24.

[10] Martorell, R., Leslie, J., and Moock, P.R., Characteristics and determinants of child nutritional status in Nepal, The American Journal of Clinical Nutrition,1984,39: 74-86

[11] Costello, A. M. De L., Growth velocity and stunting in rural Nepal, Archives of Disease in Childhood, 1989, 64: 1478-1482.

[12] Goon, D.T., Amusa, L.O., Shaw, B.S., Shaw, I. and Akusu, S.W. Somatotypes of Andibila children aged 7 to 14 years in Oju, Nigeria. African Journal for Physical, Health Education, Recreation and Dance, 2013,19(3):1037-1046.

[13] Rebato, E., Jelenkovic, A. and Salces, I., Heritability of the somatotype components in Biscay families. Homo Journal of Comparative Human Biology, 2007,58(3): 199-210.

[14] Ross, W. D., and Wilson, N.C., A stratagem for proportional growth assessment. Acta Paediatrica Belgica, 1974,(Suppl. 28) :169-182.

[15] Ross, W. D., and Ward, R., Sexual dimorphism and human proportionality. In R. Hall (Ed. ), Sexual dimorphism in homo sapiens, 1982, pp. 317-361, New York: Praeger.

[16] Ross, W. D., Drinkwater, D. T., Bailey, D. A., Marshall, G. H., and Leahy, R.M., Kinanthropometry: Traditions and new perspectives. In M. Ostyn, G. Beunen, \& J. Simons (Eds. ),Kinanthropometry II (pp. 1-27). 1980, Baltimore: University Park Press.

[17] International Society for the Advancement of Kinanthropometry (ISAK), available at www.isakonline.com

[18] ISAK, International Standards for Anthropometric Assessment, ISAK manual, International Society for the Advancement of Kinanthropometry (ISAK), Lower Hutt, New Zealand, 2011

[19] Heath, B.H., and Carter, J.E.L., A modified somatotype method, American Journal of Physical Anthropology,1967,27:57-74.

[20] Carter, J.E.L.,Mirwald,R.,Heath-Roll, Bailey,B.D., Somatotypes of 7-to16 year-old boys in Saskatchewan, Canada, American Journal of Human Biology,1997,9(2):257-272.

[21] Tapia, L.U., Lizana, P.A., Orellana,Y.Z. Villagrán,F.A.,Arias,V.F.,Almagiá,A.F., Burrows, R.A., and Ivanovic,D.M., Somatotype and intellectual ability (Raven progressive matrices test) in chilean school-age children,Nutrición Hospitalaria,2013,28(5):1552-1557.

[22] Mladenova,S.,Nikolova,M.,Andreenko,E., and Boyadjiev, D., Somatotypological characterization of Bulgarian children and adolescents (Smolyan Region),Collegium Antropologicum, 2010,34(3):963-971.

[23] Duquet,W., Studie van de toepasbaarheid van de Heath \&carter somatotype-methode op kinderen van 6 tot 13 jaar ( applicability of the Heath-Carter somatotype method to 6 to 13 year old children).Ph.D Dissertation,Vrije University,Brussel, Belgium, 1980.

[24] Štêpnicka, J., Somatotype of Bohemian and Moravian youth, Acta Facultatis Medicae Universitatis Brunensis, 1976,57:233242.

[25] Farmosi,I., Results of constitutional and motor examinations of male athletes,Glasnik Antropoloskog Drustva Jugoslavije,1982,19:35-51. 
[26] Guedes,D.P., Estudos antropometricos entre escolares, Reviste Brazileire de Educao Fisica e Desportos,1983, out/mar,12-17

[27] Toriola,A.L., and Igbokwe,N.U., Relationship between perceived physique and somatotype characteristics of 10 to 18 year old boys and girls, Perceptual and Motor skills, 1985,60:878.

[28] Saar, M. The relationship between anthropometry, physical activity and motor ability in 10-17 year olds, Tartu University Press, Ph.D dissertation, Institute of Sport Pedagogy and Coaching science, University of Tartu, Tartu,Estonia, 2008.

[29] Holopainen, S., Lumiaho-Hakkinen,P., and Telema,R., Level and rate of development of motor fitness, motor abilities and skills by somatotype, Scandinavian Journal of Sports Sciences, 1984, 6(2):67-75.

[30] Marta,C., Marinho,D.A.,Costa,A.M.,Barbosa,T.M., and Marques,M.C., Somatotype is more interactive with strength than fat mass and physical activity in peripubertal children, Journal of Human Kinetics Special issue,2011,83-91.
[31] Slaughter,M.H., and Lohman, T.G., Relationship of body composition to somatotype in boys, ages 7 to 12 years, Reserach Quarterly,1977,48:750-758.

[32] Eiben,O.G., The kormend growth Study,:Somatotypes.In Physique and body composition, vol 16,ed.O.G.Eiben,pp 3752,Budapest:humanbiologia Budapestinensis, 1985.

[33] Carter,J.,E.,L., and B.,H., Heath. Somatotyping -Developments and applications, 1990, Cambridge University Press, Cambridge, pp 141-181.

[34] Kornienko,A., Tambovtseva,V., and Panasiuk, V., Morfologia, 2003:123,76- 80 .

[35] Nikolova,M., Akabaliev,V., Sivkov, S., and Mladenova,S., Body composition of children and adolescents from Plovdiv. In: Proceedings (Balkan Scientific Conference of Biology, Plovdiv, 2005). 